\title{
Sociodemographic profile of beneficiaries and comparative evaluation of ante natal care services under JSY at different health care delivery system
}

\author{
Som Nath ${ }^{1, *}$, Manjusha Nath ${ }^{2}$, Ajay Bhagoliwal ${ }^{3}$ \\ ${ }^{1}$ Assistant Professor, ${ }^{2}$ Tutor, ${ }^{3}$ Professor Bio-Statistics, ${ }^{1,3}$ Dept. of Community Medicine, ${ }^{2}$ Dept. of Pharmacology, Rama Medical \\ College Hospital \& Research Centre, Kanpur, Uttar Pradesh, India \\ *Corresponding Author: \\ Email: drsomnathrewa@gmail.com
}

\begin{abstract}
Introduction: Janani Suraksha Yojana (JSY) is a safe Motherhood intervention proposed by the Government of India to decrease the neo-natal and maternal deaths by promoting institutional delivery of babies. About 56,000 women in India die every year due to pregnancy related complications. Similarly, every year more than 13 lakh infants die within 1year of the birth. MP classified under low performing states \& JSY has completed more than seven years. So, there is a need of evaluation of demographic profile of the JSY beneficiaries and antenatal services under JSY.

Materials and Methods: It is a Health Care Institute based observational cross-sectional study including randomly selected 200 JSY beneficiary mothers from the different health care delivery System i.e. PHC,CHC, District Hospital \& Medical College Hospital; of Rewa district, Madhya Pradesh. JSY beneficiary mothers were interviewed and data collected and analyzed using epi info 2000. Chi square test was applied to assess the association between different levels of health care and quality of services.

Results: Age at marriage of JSY beneficiary mothers was seen to be gradually increasing from rural to urban area. ASHA provided ANC, TT \& IFA tablets in majority of study subjects as $39(78 \%)$ in PHC \& $44(88 \%)$ in CHC while in urban areas, 'other than ASHA' were also arranging such services. Increasing the level of health care system the number of ANC provided to the JSY beneficiary mothers were improved and it was statistically significant $\left(x^{2}=24.46, p=0.0001\right)$. It was seen that the number of ANC, number of TT \& IFA tabs were provided more as shifting towards PHC Health care settings to Medical College Hospital Settings.

Conclusion: JSY has definitely impacted upon the maternal and child health by providing health care to pregnant mother during ANC at different levels of Health Care Settings but uptake of JSY services are comparatively less at rural area.
\end{abstract}

Keywords: JSY, ASHA, Antenatal care, IFA tablets, TT Immunization.

\section{Introduction}

Janani Suraksha Yojana is a safe motherhood intervention proposed by the Government of India and launched on 12 April 2005 by the Prime Minister of India. ${ }^{1}$ It aims to decrease the maternal and neo-natal deaths by promoting institutional delivery of babies. This scheme is $100 \%$ centrally sponsored and provides delivery and post delivery care, along with cash monetary help to pregnant women. ${ }^{2}$ About 56,000 women in India die every year due to pregnancy related complications. ${ }^{3}$ Similarly, every year more than 13 lakh infants die within 1year of the birth and out of these approximately $2 / 3 \mathrm{rd}$ of the infant deaths take place within the first four weeks of life. And of this majority $(75 \%)$ of the deaths take place within $1^{\text {st }}$ week of life. Out of total early neonatal deaths, maximum deaths were reported within $1^{\text {st }}$ two days of life. In order to reduce the maternal and infant mortality, several initiatives have been launched by the Ministry of Health and Family Welfare (MoHFW) including Janani Suraksha Yojana. The success of the scheme would be determined by the increase in institutional delivery among the poor families. ${ }^{4}$ Under this initiative, eligible pregnant women are entitled to get JSY benefit and scheme also provides performance based incentives to ASHA for promoting institutional delivery. ${ }^{5}$ Over a decade after the JSY implementation under the umbrella of National Rural Health Mission, there have been declines in maternal mortality in India. The Maternal Mortality Ratio (MMR) declined to 212/100,000 live births (SRS-2007-09) ${ }^{6}$ and Infant Mortality Rate (IMR) declined to 50/1000 live births (SRS-2009). However, this rate of decline is not sufficient to achieve the goals of MMR less than $100 / 100,000$ live births and an IMR of less than $30 / 1000$ live births by the end of the 11th five year plan period. In Madhya Pradesh the Maternal Mortality Ratio is 269 maternal death per 100000 live birth (2007-09) $)^{6-8}$ \& Infant Mortality Rate (IMR) in Madhya Pradesh ${ }^{9}$ is 62 infant deaths/1000 live birth (2010), whereas in rural areas of MP it is 67 infant deaths/1000 live birth (2010) which is highest in India. It indicates that maternal and child health status is very poor in Madhya Pradesh. Madhya Pradesh is one of the High focus states ${ }^{10}$ classified in Low Performing States (LPS) category as well as Empowered Action Group (EAG) states in context of demographic and health status. So, it was decided to evaluate demographic profile of the beneficiaries and antenatal care provided under JSY\& to know the perception of beneficiaries on quality of care in our covered area under Rewa district.

\section{Materials and Methods}

It is a cross sectional study, carried out at all three levels of health care delivery system. This includes 1PHC Baikunthpur, 1 CHC Govindgarh, 1 District 
Hospital, Rewa \& at higher level Sanjay Gandhi Memorial Hospital(SGMH), attached to Government Medical College, Rewa, M.P. Study duration was one year (from October 2012 to Sept 2013). A total 200 beneficiary mothers were selected in present study who have delivered within 6 months of data collection and willing to participate and given the consent for the study. Sample size for the study was calculated by using the previous year data collected from CMHO office Rewa \& it was found that prevalence of the institutional delivery in Rewa district was $70 \%$ and after application of sample size calculation from $\mathrm{N}=4$ $\mathrm{p} \mathrm{q} / \mathrm{L}^{2}$ where $\mathrm{L}$, the allowable error was kept $10 \%$ of $\mathrm{p}$ (prevalence) hence minimum number of beneficiary mothers was found 172 and to maintain uniformity in sample size from each level of health care settings and for better precision of results the sample size was taken as 200. Government Medical College Hospital, Rewa \& District Hospital, Rewa were selected. One Community Health Centre, CHC Govindgarh \& One Primary Health
Centre, PHC Baikunthpur were selected from a total of 12 CHCs \& 29 PHCs of Rewa district respectively randomly. To ensure randomization first a list of total 12 CHCs' and 29 PHCs' in Rewa district, were arranged alphabetically and then two random numbers were generated for PHC \& CHC. Then that PHC's \& $\mathrm{CHC}$ 's were selected bearing the serial number corresponding to the above generated random number. At each health care settings, 50 beneficiary mothers were selected from the list of eligible mothers taking JSY benefit by simple randomization using the same protocol explained above. A pre-tested, semi-structured questionnaire based proforma was set \& data was collected and analyzed by using epi info 2000 \& chi square test appropriately. The record of beneficiaries registered for the year 2012 was taken from respective Health Centre for analysis in the study.

\section{Results}

Table 1: Comparison of socio-demographic profile of beneficiaries at Different levels of health care delivery setting in Rewa district $(\mathbf{n}=\mathbf{2 0 0})$

\begin{tabular}{|c|c|c|c|c|c|c|c|c|}
\hline \multirow{2}{*}{\multicolumn{2}{|c|}{$\begin{array}{l}\text { Socio-demographic } \\
\text { variables of } \\
\text { beneficiaries }\end{array}$}} & \multicolumn{4}{|c|}{ Type of Health Centre } & \multirow[b]{2}{*}{ Total } & \multirow[t]{2}{*}{ Chi-Square } & \multirow[t]{2}{*}{$P$ value } \\
\hline & & \multirow{2}{*}{$\begin{array}{c}\begin{array}{c}\text { PHC } \\
\text { Baikunthpur }\end{array} \\
41(82) \\
\end{array}$} & \multirow{2}{*}{$\begin{array}{c}\text { CHC } \\
\text { Govindgarh }\end{array}$} & \multirow{2}{*}{$\begin{array}{c}\text { DH } \\
\text { Rewa } \\
10(20)\end{array}$} & \multirow{2}{*}{$\begin{array}{c}\text { SGMH } \\
8(16.0\end{array}$} & & & \\
\hline \multirow{3}{*}{$\begin{array}{l}\text { Age at marriage } \\
\text { (in Years) }\end{array}$} & $<18$ & & & & & $92(46.0)$ & \multirow{3}{*}{65.86} & \multirow{3}{*}{.000} \\
\hline & $\geq 18$ & $9(18)$ & $17(34)$ & $40(80)$ & $42(84)$ & $108(54)$ & & \\
\hline & Total & $50(100)$ & $50(100)$ & $50(100)$ & $50(100)$ & $200(100)$ & & \\
\hline \multirow{3}{*}{$\begin{array}{l}\text { Age At 1st } \\
\text { Pregnancy } \\
\text { (in Years) }\end{array}$} & $<21$ & $42(84)$ & $35(70)$ & $14(28)$ & $11(22)$ & $102(51)$ & \multirow{3}{*}{56.42} & \multirow{3}{*}{.000} \\
\hline & $\geq 21$ & $8(16)$ & $15(30)$ & $36(72)$ & $39(78)$ & $98(49)$ & & \\
\hline & Total & $50(100)$ & $50(100)$ & $50(100)$ & $50(100)$ & $200(100)$ & & \\
\hline \multirow{3}{*}{ Literacy status } & Illiterate & $44(88)$ & $38(76)$ & $15(30)$ & $14(28)$ & $111(55.5)$ & \multirow{3}{*}{58.36} & \multirow{3}{*}{.000} \\
\hline & literate & $6(12)$ & $12(24)$ & $35(70)$ & $36(72)$ & $89(44.5)$ & & \\
\hline & Total & $50(100)$ & $50(100)$ & $50(100)$ & $50(100)$ & $200(100)$ & & \\
\hline \multirow{3}{*}{$\begin{array}{l}\text { Economic } \\
\text { Status }\end{array}$} & Earning & $14(28)$ & $26(52)$ & $39(78)$ & $3672)$ & $115(57.5)$ & \multirow{3}{*}{31.32} & \multirow{3}{*}{.000} \\
\hline & $\begin{array}{c}\text { Not } \\
\text { Earning }\end{array}$ & $36(72)$ & $24(48)$ & $11(22)$ & $14(28)$ & $85(42.5)$ & & \\
\hline & Total & $50(100)$ & $50(100)$ & $50(100)$ & $50(100)$ & $200(100)$ & & \\
\hline
\end{tabular}

Figure in parenthesis indicate percentage; PHC=Primary Health Centre, $\mathbf{C H C}=$ Community Health Centre, DH=District Hospital, SGMH=Sanjay Gandhi Memorial Hospital, Rewa.

Table 1 shows age at marriage of majority of beneficiaries at PHC Baikunthpur (82\%) were less than 18 years while number of beneficiaries having age at marriage $\geq 18$ years, was at PHC Baikunthpur 18\%, CHC Govindhgarh 34\%, DH Rewa 80\% \& SGMH, Rewa $84 \%$. Age at the time of $1^{\text {st }}$ pregnancy was $\leq 21$ years in most of the Beneficiaries of rural area while number of beneficiaries of Age at $1^{\text {st }}$ pregnancy $\geq 21$ years, was at PHC Baikunthpur 16\%, CHC Govindhgarh 30\%, DH Rewa $72 \%$ \& SGMH, Rewa $78 \%$. Number of literate beneficiaries was at PHC Baikunthpur 12\%, CHC Govindhgarh 24\%, DH Rewa $70 \%$ \& SGMH, Rewa $72 \%$. Number of beneficiaries with earning, was seen to be at PHC Baikunthpur 28\%, CHC Govindhgarh 52\%, DH Rewa 78\% \& SGMH, Rewa $72 \%$.

Table 2: Comparison of work done by ASHA for beneficiaries at various levels of health care delivery setting in Rewa district $(\mathbf{n}=\mathbf{2 0 0})$

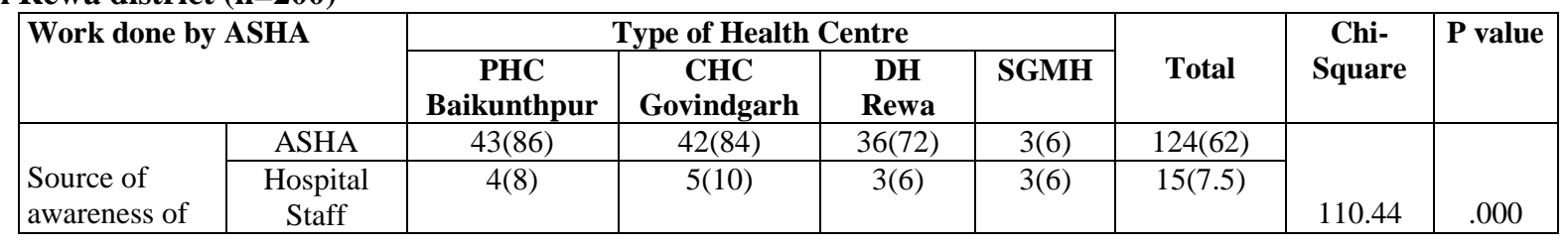




\begin{tabular}{|c|c|c|c|c|c|c|c|c|}
\hline \multirow[t]{2}{*}{$\begin{array}{l}\text { JSY scheme } \\
\text { among } \\
\text { Beneficiary) }\end{array}$} & $\begin{array}{c}\text { Others } \\
\text { (Media, } \\
\text { Freinds etc) }\end{array}$ & $3(6)$ & $3(6)$ & $11(22)$ & $44(88)$ & $61(30.5)$ & & \\
\hline & Total & $50(100)$ & $50(100)$ & $50(100)$ & $50(100)$ & $200(100)$ & & \\
\hline \multirow{3}{*}{$\begin{array}{l}\text { Motivator for } \\
\text { institutional } \\
\text { Delivery }\end{array}$} & ASHA & $41(82)$ & $46(92)$ & $29(58)$ & $35(70)$ & $151(75.5)$ & \multirow{3}{*}{17.59} & \multirow{3}{*}{.001} \\
\hline & $\begin{array}{c}\text { Other than } \\
\text { ASHA }\end{array}$ & $9(18)$ & $4(8)$ & $21(42)$ & $15(30)$ & $49(24.5)$ & & \\
\hline & Total & $50(100)$ & $50(100)$ & $50(100)$ & $50(100)$ & $200(100)$ & & \\
\hline \multirow{3}{*}{$\begin{array}{l}\text { Arrange } \\
\text { Antenal Care, } \\
\text { TT \& IFA tab }\end{array}$} & ASHA & $39(78)$ & $44(88)$ & $27(54)$ & $33(66)$ & $143(71.5)$ & \multirow{3}{*}{15.97} & \multirow{3}{*}{.001} \\
\hline & Others & $11(22)$ & $6(12)$ & $23(46)$ & $17(34)$ & $57(28.5)$ & & \\
\hline & Total & $50(100)$ & $50(100)$ & $50(100)$ & $50(100)$ & $200(100)$ & & \\
\hline \multirow{3}{*}{$\begin{array}{l}\text { Accompanied } \\
\text { to health } \\
\text { center }\end{array}$} & ASHA & $46(92)$ & $47(94)$ & $43(86)$ & $36(72)$ & $172(86)$ & \multirow{3}{*}{12.29} & \multirow{3}{*}{.006} \\
\hline & Others & $4(8)$ & $3(6)$ & $7(14)$ & $14(28)$ & $28(14)$ & & \\
\hline & Total & $50(100)$ & $50(100)$ & $50(100)$ & $50(100)$ & $200(100)$ & & \\
\hline
\end{tabular}

Figure in parenthesis indicate percentage; ASHA=Accredited Social Health Activist, TT=Tetanus Toxoid Vaccine, IFA= Iron Folic Acid Tablet

Table 2 in present study shows ASHA is the main source for creating awareness about JSY to 41(82\%) of beneficiaries in PHC and $42(84 \%)$ in $\mathrm{CHC}$. She motivated beneficiaries to deliver in an institution viz. PHC 41 (82\%) \& CHC46 (92\%).ASHA arranges antenatal care, TT \& IFA tablets in majority of study subjects as $39(78 \%)$ in PHC \& 44(88\%) in CHC while in urban district areas, 'other than ASHA' were arranging such services. ASHA accompanied to beneficiaries in PHC 46 (92\%), CHC 47 (94\%), DH $43(86 \%)$ \& SGMH 36 (72\%).

Table 3: Comparison of health services provided to beneficiaries at different levels of health care delivery setting in Rewa district $(\mathbf{n}=\mathbf{2 0 0})$

\begin{tabular}{|c|c|c|c|c|c|c|c|c|}
\hline \multirow{2}{*}{\multicolumn{2}{|c|}{$\begin{array}{l}\text { Health Services provided to } \\
\text { Beneficiary }\end{array}$}} & \multicolumn{4}{|c|}{ Type of Health Centre } & \multirow[b]{2}{*}{ Total } & \multirow[t]{2}{*}{ Chi-Square } & \multirow[t]{2}{*}{$P$ value } \\
\hline & & \multirow{2}{*}{$\begin{array}{c}\begin{array}{c}\text { PHC } \\
\text { Baikunthpur }\end{array} \\
39(78) \\
\end{array}$} & \multirow{2}{*}{$\begin{array}{c}\begin{array}{c}\text { CHC } \\
\text { Govindgarh }\end{array} \\
36(72) \\
\end{array}$} & \multirow{2}{*}{$\begin{array}{c}\text { DH } \\
\text { Rewa }\end{array}$} & \multirow{2}{*}{$\begin{array}{c}\text { SGMH } \\
19(38) \\
\end{array}$} & & & \\
\hline Number of & $<4$ & & & & & $116(58)$ & \multirow[b]{3}{*}{24.466} & \multirow[b]{3}{*}{.000} \\
\hline Antenatal Care & $\geq 4$ & $11(22)$ & $14(28)$ & $28(56)$ & $31(62 \%)$ & $84(42)$ & & \\
\hline provided & Total & $50(100)$ & $50(100)$ & $50(100)$ & $50(100)$ & $200(100)$ & & \\
\hline \multirow[t]{3}{*}{$\begin{array}{l}\text { TT } \\
\text { Immunization }\end{array}$} & $\begin{array}{c}\text { Partially } \\
\text { Immunized }\end{array}$ & $4(8 \%)$ & $3(6)$ & $1(2 \%)$ & $1(2)$ & $9(4.5)$ & \multirow{3}{*}{3.14} & \multirow{3}{*}{.370} \\
\hline & $\begin{array}{c}\text { Fully } \\
\text { Immunized }\end{array}$ & $46(92)$ & $47(94)$ & $49(98 \%)$ & 49(98) & $191(95.5)$ & & \\
\hline & Total & $50(100)$ & $50(100)$ & $50(100)$ & $50(100)$ & $200(100)$ & & \\
\hline \multirow{4}{*}{$\begin{array}{l}\text { IFA Tablets } \\
\text { consumed }\end{array}$} & $0-30 \mathrm{Tab}$ & $3(6)$ & $2(4)$ & $1(2)$ & $1(2)$ & $7(3.5)$ & \multirow{4}{*}{23.205} & \multirow{4}{*}{.001} \\
\hline & 31-60 Tab. & $19(38)$ & $19(38)$ & $7(14)$ & $4(8)$ & $49(24.5)$ & & \\
\hline & 61-100 Tab. & $28(56)$ & $29(58)$ & $42(84)$ & $45(90)$ & $144(72)$ & & \\
\hline & Total & $50(100)$ & $50(100)$ & $50(100)$ & $50(100)$ & $200(100)$ & & \\
\hline
\end{tabular}

Table 3 shows beneficiaries who were provided less than 4 Antenatal visits were 39 (78\%), $36(72 \%)$, $22(44 \%)$ \& $19(38 \%)$ respectively in $\mathrm{PHC}$ Baikunthpur, CHC Govidgarh, DH \& SGMH. In case of beneficiary mothers who were provided 4 or more Antenatal visits, were 11 (22\%), 14 (28\%), 28 (56\%) and $31(62 \%)$ respectively in PHC Baikunthpur, CHC Govindhgarh, DH \& SGMH. Present study shows the number of TT fully immunized subjects at PHC, CHC were $92 \%$ \& $94 \%$ respectively while $98 \%$ at both, DH \& SGMH. In the present study only few beneficiary mothers who consumed less (0-30) IFA Tablets viz. PHC Baikunthpur 3(6\%), CHC Govindhgarh 2 (4\%), DH $1(2 \%) \&$ SGMH 1 (2\%). Those consumed 31-60 IFA Tabs were $19(38 \%)$ beneficiaries at both PHC
Baikunthpur \& CHC Govindhgarh \& 7 (14\%) \& 4 (8\%) at $\mathrm{DH} \& \mathrm{SGMH}$ respectively. And the beneficiaries consumed 61-100 IFA Tabs were 28 (56\%), 29 (58\%), $42(84 \%) \& 45(90 \%)$ respectively in $\mathrm{PHC}, \mathrm{CHC}, \mathrm{DH}$ $\&$ SGMH. It was seen that the number of ANC, number of TT \& IFA tabs were provided more as shifting towards PHC Health care settings to Medical College Hospital Settings. 
Table 4: Reasons of less consumption of IFA Tablets by the beneficiaries at different levels of health care delivery settings in Rewa district

\begin{tabular}{|c|c|c|c|c|c|c|c|}
\hline \multirow{3}{*}{$\begin{array}{l}\text { Reason of Less } \\
\text { Consumption of IFA } \\
(\mathrm{n}=57)\end{array}$} & \multicolumn{4}{|c|}{ Type of Health Centre $(n=57)$} & \multirow[b]{3}{*}{ Total } & \multirow[b]{3}{*}{ ' $\mathbf{Z}$ ' } & \multirow[b]{3}{*}{$P$ value } \\
\hline & \multicolumn{2}{|c|}{ Rural } & \multicolumn{2}{|c|}{ Urban } & & & \\
\hline & $\begin{array}{c}\text { PHC } \\
\text { Baikunthpur }\end{array}$ & $\begin{array}{c}\text { CHC } \\
\text { Govindgarh }\end{array}$ & $\begin{array}{c}\text { DH } \\
\text { Rewa }\end{array}$ & SGMH & & & \\
\hline $\begin{array}{l}\text { Less IFA Tablets } \\
\text { received }\end{array}$ & $6(10.52)$ & $5(8.78)$ & 0 & 0 & $11(19.3)$ & ---- & ---- \\
\hline No advice given & $4(7.02)$ & $5(8.78)$ & $2(3.5)$ & $1(1.75)$ & $12(21.1)$ & $\begin{aligned} & \mathrm{Z} \\
= & 2.5\end{aligned}$ & $\begin{aligned} & \mathrm{P} \\
= & 0.01\end{aligned}$ \\
\hline Not aware & $3(5.26)$ & $4(7.02)$ & $2(3.5)$ & $1(1.75)$ & $10(17.5)$ & $\begin{aligned} & Z \\
= & 1.79\end{aligned}$ & $\begin{aligned} & \mathrm{P} \\
= & 0.07\end{aligned}$ \\
\hline $\begin{array}{l}\text { Fear of Side Effects } \\
\text { (nausea \& headache } \\
\text { etc.) }\end{array}$ & $9(15.79)$ & $8(14.03)$ & $4(7.02)$ & $3 \%(5.26)$ & $24(42.1)$ & $\begin{aligned} & Z \\
= & 1.9\end{aligned}$ & $\begin{array}{c}\mathrm{P} \\
=0.057\end{array}$ \\
\hline
\end{tabular}

Table 4 shows number of beneficiaries consuming less IFA tablets due to fear of side effects, were respectively $9(15.79 \%)$ in PHC Baikunthpur, 8(14.03)CHC Govindhgarh, 4(7.02) DH \& 3\% (5.26)SGMH. Other reasons for less consumption of IFA tablets were either unawareness or no advice given to beneficiary mothers in PHC \& CHC.

\section{Discussion}

Socio-demographic profile of beneficiaries at Different levels of health care delivery System in Rewa district shows similar finding as shown in other studies. ${ }^{11,12}$ Age at marriage of majority of beneficiaries of Rural area, PHC Baikunthpur (82\%) were less than 18 years while age at marriage $\geq 18$ years, was seen to be gradually increasing from rural to urban area viz. PHC Baikunthpur 18\%, CHC Govindhgarh 34\%, DH Rewa $80 \%$ and SGMH, Rewa $84 \%$. This association between place of residence and age at marriage is statistically significant. (Chi-square is 65.86 and $p$ $<0.05)$. Present findings are almost similar to findings of a study conducted by Mahawar et al (2013) on evaluation of different aspects of Janani Suraksha Yojna in Indore District, Madhya Pradesh, ${ }^{13}$ observed that at PHC total $31(62 \%$ )of females were married when they were less than 18 years. Age at $1^{\text {st }}$ pregnancy was $\leq 21$ years, seen mostly in Beneficiaries of rural area $42(84 \%)$ while number of beneficiaries of age at first pregnancy $\geq 21$ years is gradually increasing from rural to urban district areas. It is seen that there is significant association between beneficiary of different health centre level and age at $1^{\text {st }}$ pregnancy. Thus there is need of proper health education towards raising age at marriage $\&$ age at $1^{\text {st }}$ pregnancy particularly in rural area which has positive impact on maternal \& child health under JSY. Literacy status of beneficiary mothers availing JSY services shows majority were illiterate in rural area, while literacy status of beneficiaries were seen to be gradually increasing from rural to urban area. Thus there is a need to motivate the beneficiary and ensure faith in the Government health facilities. Findings of our study are almost similar to findings of a study conducted by Mahawar et al. ${ }^{13}$
There is a statistically significant association between beneficiary of different types of health centre and Literacy Status or their earnings. Number of Beneficiaries with proper earnings at different health care level, was seen to be gradually increasing from rural to urban area. Similar trends of financial status of beneficiary at different health care level was seen in a study conducted by Mahawar et al (2013). ${ }^{13}$

In present study, role of ASHA in creating awareness about JSY, was seen more in rural area i.e. PHC \& CHC while in urban area DH \&SGMH, awareness was by other sources. There is an association between Source of awareness of JSY scheme among beneficiary mothers and different levels of health system \& was found to be statistically significant. ASHA motivated beneficiaries for institutional delivery morein PHC41 (82\%) \& CHC46 (92\%). It is found that there is a statistically significant association between motivator for institutional delivery and different levels of health delivery system. Similar trends at different health care level was seen in a study conducted by Mahawar et al (2013) as almost 50\% of beneficiaries were motivated by ASHA for institutional delivery. ${ }^{13}$ Tripathi $\mathrm{R}$ et al also found that ASHA played a major role $(65 \%$ of the utilizers) in motivation for institutional delivery. ${ }^{11}$

ASHA provided antenatal care, TT \& IFA tablets in majority of study subjects as $39(78 \%)$ in PHC and $44(88 \%)$ in CHC while in urban areas, 'other than ASHA' were arranging such services. There is an association between those arranging antenatal care, TT \& IFA tablets among beneficiary mothers and different levels of health centre \& was found to be statistically significant. ASHA accompanied to beneficiaries in PHC $46(92 \%)$ i.e. maximum in rural area while gradually decreases to DH $43(86 \%)$ \& SGMH 36 (72\%). This implies that there is a significant association between types of health centre and Work accompanied to beneficiary [Table 2]. Similar trends was seen in a study conducted by Mahawar et al (2013) as ASHA accompanied $88 \%$ of the beneficiary to health center for delivery. One major reason for this was that the beneficiaries also fail to inform. ${ }^{13}$ 
Present study shows beneficiary mothers who were provided 4 or more than 4 antenatal visits, were 11 (22\%), $14(28 \%), 28(56 \%)$ and $31(62 \%)$ respectively in PHC Baikunthpur, CHC Govindhgarh, DH \& GMH. Hence it was observed that with increasing the level of health care system the number of ANC provided to the beneficiary mothers improved and it was statistically significant $\left(\mathrm{x}^{2}=24.46, \mathrm{p}=0.0001\right)$. (Table 3)This difference of ANC service provided at different health care levels at Rewa could be due to more effective implementation of JSY services at higher centers but equal services should be provided at all centers. The report published by UNICEF 2012 on Children health status found that in India $75 \%$ pregnant women received at least $1 \mathrm{ANC}$ visit and $51 \%$ pregnant mother received 4 ANC visits during Pregnancy. Even GOI, Ministry of Health and family welfare department in 2011 also reported the same finding regarding ANC coverage among pregnant mothers. ${ }^{8}$ Coverage Evaluation Survey (CES) in India conducted by UNICEF 2009 reported - 3 or > ANC in $68.7 \%$ \& Institutional deliveries $72.9 \%$ of pregnant mothers. These observations were somewhat similar to our present study. ${ }^{14}$ In study conducted by Mahawar et al (2013), 42.8\% had three antenatal checkups. ${ }^{13}$ According to DLHS data ${ }^{15}$ also the percentage of females receiving $3 \mathrm{ANC}$ in rural area is $37.1 \%$.

Present study shows that TT immunization status (Fully) of beneficiaries at different levels of health delivery system is nearly similar; at PHC (92\%), CHC (94\%), DH (98\%) \& SGMH (98\%). Few partially immunized subjects were found at different health centres, at PHC 4 (8\%), CHC $3(6 \%)$, DH $1(2 \%)$ and SGMH $1(2 \%)$ so the difference of TT immunization among different health care levels was statistically not significant $(p=0.37)$ (Table 3). Similarly the report published by UNICEF 2012 on children health status was that in India $87 \%$ pregnant women got TT during pregnancy.

In the present study only few beneficiaries consumed less (0-30) IFA Tablets viz. at PHC Baikunthpur 3(6\%), CHC Govindhgarh 2(4\%), DH $1(2 \%) \&$ SGMH 1(2\%). Those consumed 31-60 IFA Tabs were $19(38 \%)$ beneficiaries at both PHC Baikunthpur \& CHC Govindhgarh while at DH 7(14\%) \& SGMH 4 (8\%). And the beneficiaries consumed 61100 IFA Tabs were 28 (56\%), 29 (58\%), 42 (84\%) \& 45 (90\%) respectively at PHC Baikunthpur, CHC Govindhgarh, DH \& SGMH. Hence it was seen that the number of IFA Tabs were consumed more as shifting towards PHC Health care levels to Medical College Hospital levels. The distribution of number of IFA tablets consumed by the beneficiary mothers among different health care levels is found to be statistically significant (Table 3). This type of distribution of services among various health care levels needs to reorient of JSY services. Other studies like Gupta S. et al (2008) found $96.14 \%$ mothers were fully immunized against tetanus. $\mathrm{He}$ also observed that $48.2 \%$ beneficiary mothers received 50-100 IFA tablets and $48 \%$ received less than 50 IFA tablets. ${ }^{16}$ Present study shows number of beneficiaries consuming less IFA tablets due to fear of side effects, were $9,8,4 \& 3$ respectively in PHC Baikunthpur, CHC Govindhgarh, DH \& SGMH. Other reasons for less consumption of IFA tabs were either not awareness or no advice given to beneficiary mothers in PHC \& CHC. The difference in the number of IFA tablets consumed by the beneficiaries giving the reason 'No advice given' among rural \& urban health centres was found to be statistically significant $(\mathrm{Z}=2.5, \mathrm{p}=0.01)$ [Table 4 ]

\section{Conclusion}

Evaluation of Socio-demographic profile of JSY beneficiary mothers \& ANC services provided at different level of health care delivery system was done and proper feedback from the site of implementation was collected and the lacunas identified and reported for rectification. Apart from promoting the institutional delivery, socio-demographic profile of the beneficiary mothers like age of marriage $\&$ age at the time of $1^{\text {st }}$ pregnancy and their Literacy status \& economic status, of different health care settings was found to be low but above status was comparatively better in urban areas as compared to rural areas. It has an indirect impact on maternal mortality and infant mortality. Above status has improved in urban areas but is still a challenge in rural areas. JSY has definitely impacted upon the maternal and child health by providing health care to pregnant mothers during ANC but JSY services and awareness about JSY for improving maternal health was comparatively less at rural level. It demands some more needful qualitative research to explore the various performances deciding factors and remedial action will definitely make this scheme more effective $\&$ fruitful.

Recommendations: The eligible beneficiaries must be made aware about the Janani Suraksha Yojana and its benefits. Special JSY awareness campaign should be arranged particularly in unapproached rural areas. This can be done by various IEC activities \& Health education programmes. Minimum 4 ANC should be given top priority and the beneficiaries should be motivated and counseled regarding antenatal care, TT immunization, IFA tablets \& advantages of institutional delivery.

\section{References}

1. Ministry of Health and Family Welfare (2017). Janani Suraksha Yojana Guidelines for Implementation, Ministry of Health \& Family Welfare, Government of India. Available from: http://www.ilo.org/dyn/travail/ docs/683/ JananiSurakshaYojanaGuidelines/Ministry ofHealthandFamilyWelfare.pdf. [Accessed on 2017 July 19] 
2. Park K. Park's Text Book of Preventive and Social Medicine. 22nd edition. Jabalpur: Bhanot Publishers; 2013. Chapter 7: Health Programmes in India; pp 419.

3. WHO, UNICEF, UNFPA and World Bank Estimates. 2012. Trends in Maternal Mortality: 1990 to 2010. Available from: http://www.who.int/reproductivehealth/publications/moni toring/ 9789241503631/en/. [Last accessed on 2014 Oct 04].

4. Janani Suraksha Yojana: Features and Frequently Asked Questions and Answers. Ministry of Health and Family Welfare. Maternal Health Division, Government of India. New Delhi: 2006. Available from: http://www.mohfw.nic.in/WriteReadData/1892s/file2899526408.pdf.[Last accessed on 2014 Oct 04]

5. Ministry of Health and Family Welfare. Government of India. Accredited Social Health Activist (ASHA) Guidelines. New Delhi: National Rural Health Mission; 2005 [Available from http://nrhm.gov.in/communitisation/asha/about-asha. html]. [Last accessed Nov 20, 2013].

6. Office of Registrar General, India. Maternal \& Child Mortality and Total Fertility Rates Sample Registration System (SRS). Office of Registrar General, India. 7th July 2011. Available athttp://censusindia.gov.in/vital_statistics/SRS_Bulletins/ MMR_release_070711.pdf [Last Accessed on Dec 2, 2013].

7. NHM. Statewise information. National Health Mission, Ministry of Health and Family Welfare, Government of India. Available at http://nrhm.gov.in/nrhm-in-state/statewiseinformation.html. Last accessed on Nov 30, 2013.

8. Ministry of Health and Family Welfare, Government of India. NRHM 'The Progress So Far', Available at http://www.mohfw.nic.in/NRHM/Documents/NRHM_Th e_Progress_so_far. pdf Accessed on Nov.27,2012.

9. Census (2011), Primary Census Abstracts, Registrar General of India, Ministry of Home Affairs, Government of India, Available at http://www.censusindia.gov.in/2011 census/PCA/ pca_highlights/pe_data.html. Accessed on 14 July 2013.
10. National Rural Health Mission. Executive summary. All India Summary of NRHM. 2010. Available from:http://mohfw.nic.in/NRHM/Documents/Executive_s ummery_March10.pdf [Accessed Mar 2 2012].

11. Shobha M, Tripathi R, Khattar P, Nair K, Thekre Y., Dhar N et al. Rapid appraisal of Functioning of Janani Suraksha Yojana in South Orissa MKCG Medical College, Berhampur. Health and population: perspectives and issues 2008;31(2):126-132.

12. Mohapatra B, Utsuk D, Tiwari VK, Gupta S, Nair KS, Vivek A, et al An Assessment to Understand the Functioning and Impact of Janani Surkasha Yojana in Orissa Department of Community Medicine, S.C.B. Medical College Cuttack. HPPI Vol. 31 issue 2 2008:120126.

13. Mahawar P, Anand S, Dixit S, Bhagwat AK, Sakalle S, Yesikar V. Evaluation of Different Aspects of Janani Suraksha Yojna in Indore District, Madhya Pradesh. Natl Community Med 2013; 4(3): 512-515.

14. UNICEF. 2009 Coverage Evaluation Survey. Government of India, Ministry of Health \& Family Welfare and UNICEF. 2009. Available from: http://www.unicef.org/india/health_5578.htm and http://www.unicef.org/india/National_Fact_Sheet_CES_2 009.pdf. [Last accessed on 2012 Jan 20].

15. Results of DLHS and facility survey coordinated by International Institute for Population Sciences Mumbai 2003:12 Available from http://www.iipsindia.org/nfhs3.html. [last accessed on 2012 Jul 5]

16. Gupta SK, Pal DK, Tiwari R, Garg R, Shrivastava AK, Sarawagi R, et al. Impact of Janani Suraksha Yojana on institutional delivery rate and maternal morbidity and mortality: An observational study in India. J Health Popul Nutr. 2012;30:464-71. [PMC free article] [PubMed] 